married and/or single names, and addresses, first resident post held and date, to the honorary secretaries of the club, at the Mancheste Royal Infirmary, together with similar details of any women old residents known to them so that a complete list can be compiled in preparation for the next dinner to be held in October 1979. Membership of the club is automatic-there is no entrance fee and no subscription.

\section{Equipment for the disabled}

Home Management is the third of the new Equipment for the Disabled booklets to be published in the 4 th edition. Completely revised and expanded, it shows standard consumer goods, simple home-made aids, and specially designed equipment. It also contains guidelines for selecting equipment and in planning kitchen layouts and suggests solution to some home management problems. The booklet gives brief details of the items shown, together with manufacturers' and suppliers addresses, price, and export availability. It is intended for use by professional workers caring for disabled people, but disabled housewives may themselves find useful information. Equipment for the Disabled is at 2 Foredown Drive, Portslade, Brighton; the price of booklets is $£ 1.50$, postage extra.

\section{University applications}

Applications so far for university places in October 1977 show a $9.5^{\circ}$ increase over 1976 , with a rise in the proportion of places in education, mechanical engineering, agriculture and forestry, business management, and accounting; a slight increase in applications for medicine; and a decrease in the proportion of applications for geography, psychology, sociology, and history.

\section{London Medical Orchestra}

The London Medical Orchestra will resume rehearsals in Christ Church School, Cosway Street, London NW1 at $7.00 \mathrm{pm}$ on Tuesday 11 January. Second flute, 2nd bassoon, and all string players welcome. Particulars from Mrs A P Mason, 102 Hamilton Terrace, London NW8: 01-286 4367.

\section{People in the News}

Dr M G P Stoker has been elected Foreign Secretary of the Royal Society in succession to Sir Kingsley Dunham.

\section{COMING EVENTS}

Medical Commission on Accident Prevention -Symposium on "Fitness to work-health and accidents," 18 January, London. Details from the Commission, 50 Old Brompton Road, London SW7 3EA. (Tel 01-584 9240.)

Royal College of Radiologists-Details of meetings to be held on 21 and 22 January, London, are now available from the College, 28 Portland Place, London W1N 4DE. (Tel 01-636 4432/3.) Institute of Religion and Medicine-Conference "Degeneration or a positive contribution? The Needs of the Elderly and Infirm," 27 January, London. Details from the Organising Secretary, IRM, St Mary Abchurch Vestry, Abchurch Lane, London EC4N 7BA. (Tel 01-626 0306.)
University of Dundee-Course on "Medical education: the design and implementation of medical course," 6-26 February, Dundee. Details from the Director, Centre for Medical Education, University of Dundee, Dundee.

Royal College of Surgeons of EnglandCollege evening on "Surgery of the pancreas," 7 February, London. Details from Surgical Training Office, Royal College of Surgeons of England, 35-43 Lincoln's Inn Fields, London WC2A 3PN. (Tel 01-405 3474.)

Birmingham Medical Institute-Symposium "The causes and prevention of human handicap," 25 February, Birmingham. Details from the Birmingham Medical Institute, 36 Harborne Road, Edgbaston, Birmingham 15. (Tel 021-454 5007.)

West Middlesex Hospital-Study day on international travel and disease, 25 February, Isleworth Details from postgraduate secretary, Postgraduate Medical Centre, West Middlesex Hospital, Isleworth, Middlesex TW7 6AF. (Tel 01-560 2121 ext 294.)

Institute of Mental Subnormality-Details of the education programme for 1977 are now available from the Institute, Wolverhampton Road Kidderminster, Worcs DY10 3PP. (Tel Kidderminster 850251.)

University College London-Details of the Freud Memorial Lectures in Psychoanalysis for the Spring Term are now available from the secretary, University College London, Gower Street, London WC1E 6BT.

\section{SOCIETIES AND LECTURES}

For attending lectures marked * a fee is charged or a ticke is required. Applications should be made first to the institution concerned.

\section{Monday, 10 January}

Royal College of SuRgeons of ENGLAND- $5.30 \mathrm{pm}$, regional distribution of retinal circulation.

Wednesday, 12 January

INSTITUTE OF NeurologY-Sandoz Foundation advanced lectures, $6 \mathrm{pm}$, $\mathrm{Dr} \mathrm{D} \mathrm{N}$ Landon: The structure of normal peripheral nerve. $7 \mathrm{pm}$, Professo $P \underset{\text { pathies. }}{\mathrm{K}}$ Thomas: Classification of peripheral neuropathies.

RoYal Free HoSpITAL $-5 \mathrm{pm}$, Professor J R Batchelor:
HLA and disease associations.

Thursday, 13 January

Royal College of SuRgeons of ENGLAND-5 pm science of pinning the neck of the femur.

\section{BMA NOTICES}

\section{Diary of Central Meetings} JANUARY

12 Wed and

13 Thurs Council, 10 am.

4 Fri Central Committee for Community 18 Tues Medicine, $10 \mathrm{am}$. Joint Consultants Committee (Royal Colleg of Psychiatrists, 17 Belgrave Square, London 20 Thurs General Medical Services Committee, 27 Thurs Organisation Committee, 10 am.

\section{Division Meetings to be Held}

Members proposing to attend meetings marked * are
asked to notify in advance the honorary secretary concerned.

Aldershot and Farnham-At Frimley Park Hospital, Thursday, 13 January, $7.30 \mathrm{pm}$, divisional symposium on the work of the Army Personnel Research
Establishment. Barnet and Finchley-At Barnet General Hospital Wednesday, 12 January, 8 for 8.15 pm, joint meeting with Finchley and Barnet Dental Association, Mr J wesser: "Demarcation disputes in ear nose and throat." Blackpool-At Savoy Hotel, Wednesday, 12 Baneriee: "A modern geriatric problem-the anaemia of chronic disorders."* (Guests are invited.)

Bradford and Airedale-At Bradford Royal Infirmary, Wednesday, 12 January, 8.30 pm, meeting.
Bromley-At Farnborough Hospital, Tuesday, 11

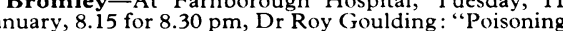
Ealing-At King Edward Memorial Hospital,

East Norfolk and Norwich-At Norfolk and Norwich Hospital, Wednesday, 12 January, $7.30 \mathrm{pm}$ Norwich and District Branch of the Pharmaceutica Society invites members to a lecture by Professor J M Cameron: "Poisoning - accident, suicide or murder ?" Holland Lincs-At Boston General Hospital, Saturday, 15 January, $7.30 \mathrm{pm}$, joint meeting with customs officers, veterinary surgeons, senior police Dr D A Robinson: "Rabies."* (Followed by buffet

Huddersfield-At Huddersfield Royal Infirmary, Monday, 10 January, $8.15 \mathrm{pm}$, business meeting. Lancaster-At Strathmore Hotel, Frida

January, 8 for $8.30 \mathrm{pm}$, annual dinner dance. * Manchester - At Boyd House, Monday, 10 January,
$8.30 \mathrm{pm}, \mathrm{Dr} \mathrm{J}$ D J Havard: "Professionalism and industrial unionism." ${ }^{\text {North Warwickshire-At George Eliot Hospital, }}$ North Warwickshire-At George Eliot Hospital,
Tuesday, 11 January, $8 \mathrm{pm}$, clinical meeting. Wakefield-At Holmfield House, Thursday, 13 January, 7.30 for $8 \mathrm{pm}$, dinner/lecture, speaker Dr Ralph Lawrence: "Look back with pleasure."* West Berkshire-At Royal Berkshire Hospital, "Wednesday, 12 January, 8.30 pm, Mr A R

\section{UNIVERSITIES AND COLLEGES}

\section{LONDON}

MD-Elizabeth J L Heathcote, Parveen J Kumar.

LIVERPOOL

Appointments-I Taylor, W D George (senior lecturers, clinical, in surgery).

LEEDS

MD-S G Tan.

\section{APPOINTMENTS}

Birmingham Area Health Authority (Teaching)Dr P P Mayer (consultant physician in geriatric medicine).

City and East London Area Health Authority (TEACHING)-The following consultants have been appointed: $\mathrm{Mr} O \mathrm{O} J$ A Gilmore (surgeon); Dr A G Cudworth (physician); Dr J G Gawler, Dr D M Park neurologists); Mr A M I Paris (urologist); Dr F W Murphy (area medical
community physician).

Cambridgeshire Area Health Authority (Tfaching) -Dr S Hagard (consultant in community medicine)

\section{Corrections}

Postural proteinuria and lipoid nephrosis of 58 years' duration

We regret that an error occurred in the short report by $\mathrm{Dr} M \mathrm{~L}$ Simenhoff (25 December, p 1540). In the third paragraph of the case report the serum calcium concentration should read " $2.2 \mathrm{mmol}(4.4 \mathrm{mEq}) / \mathrm{l}$."

\section{Notice to authors}

When original articles and letters for publication are not submitted exclusively to the British Medical Fournal this must be stated. For detailed instructions to authors see page 6 of the issue dated 1 January 1977.

Correspondence on editorial business should be addressed to the Editor, British Medical fournal, BMA House, Tavistock Square, London WC1H 9JR Telephone: 01-387 4499. Telegrams: Aitiology, London WC1. Communications will not be acknowledged unless a stamped addressed postcard or an international reply coupon is enclosed.

Authors wanting reprints of their articles should notify the Publishing Manager, BMA House, Tavistock Square, WC1H 9JR, on receipt of proofs.

\section{British Medical Journal 1977}

All Rights Reserved. No part of this publication may be reproduced, stored in a retrieval system, or transmitted, in any form or by any means, electronic, mechanical, photocopying, recording or otherwise, without the prior permission of the British Medical fournal. 